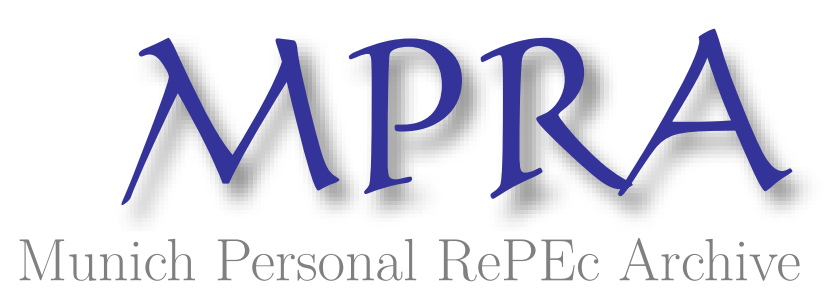

\title{
Education and youth in post-independent Eritrea: An analytical study
}

Rena, Ravinder

Department of Business and Economics, Eritrea Institute of

Technology, Mai Nefhi, Asmara, The State of Eritrea

January 2006

Online at https://mpra.ub. uni-muenchen.de/11119/

MPRA Paper No. 11119, posted 16 Oct 2008 04:37 UTC 
Rena, Ravinder (2006) "Education and Youth in Post-independent Eritrea - An Analytical Study", Albany (USA): The African Symposium (ISSN: TX 6-342-323), Volume 6., No. 3 and 4 (September and December) , pp.85-94 (An On-line Educational Research Quarterly Journal - A Publication of the African Educational Research Network).

\title{
EDUCATION AND YOUTH IN POST-INDEPENDENT ERITREA - AN ANALYTICAL STUDY
}

\author{
Ravinder Rena \\ Assistant Professor of Economics, Dept. of Business and Economics, Eritrea Institute of \\ Technology, Post box: 7956, Asmara, The state of Eritrea \\ Email: ravinder_rena@yahoo.com
}

\begin{abstract}
The efficiency of any education and training system is often judged by how well this system prepares the youth for gainful employment and thus bring a positive social and economic change. The students in Eritrea need to acquire appropriate knowledge and skills as part of their education and training. The paper mainly deals with the areas of education and economic development, education and youth. In addition, it also highlights some of the problems and challenges of education in post-independent Eritrea. The methodology used in this paper is essentially a descriptive analysis of data obtained from secondary sources, mainly government and Ministry of Education documents, survey reports, research articles, books and other published, and unpublished, materials on Eritrea.
\end{abstract}

Keywords: Education, Youth, Eritrea, Social change and Development, Human capital.

\begin{abstract}
1. INTRODUCTION
Education has long been considered a corner-stone of economic growth and social development and the principle means of improving the welfare of individuals. Education, in general, plays a significant role in economic planning and development. Higher education, however, also contributes to human resource development in a variety of ways (Rena, 2000: 2). Higher Educational institutions are responsible for fostering a country's professional personnel, including the managers, scientists, engineers, doctors, lawyers, teachers, administrators and technocrats who participate in the development, adoption, and dissemination of innovations in the economy. Such institutions should create new knowledge through research and advanced training, and serve as a conduit for its transfer, adoption and dissemination (Psacheropoulos and Woodhall, 1985).
\end{abstract}

Education is viewed as a strategic tool for development; therefore, the content of the educational system needs to be reviewed carefully. The education system in Eritrea must be geared up, not only at raising the general, social and scientific knowledge of the youth, but is must also equip the youth/individual with skills that would enable one to lead a productive, sustainable life. Education is the primary creator and conveyor of knowledge. It helps youth preserve and change society. Education also helps youth to understand, control and harness the forces of nature. Through shaping the behavior of youths and creating confidence in the minds of youth, education provides a strong base for rational and value-oriented, nation-building progress (Woodhall, 1992). Education is an integrative process in social life. There is no doubt that education is an effective instrument for large-scale achievement and revolution in all spheres. Furthermore, it assists and accelerates economic growth (Rena, 2002).

Based on his thinking that development is "a process of expanding the real freedoms that people enjoy" (Sen, 1999), Amartya Sen suggests that education contributes to development and social change: i) directly, because of its relevance to the well-being and freedom of people, ii) indirectly through influencing social change, and iii) indirectly through influencing economic production. Sen

\footnotetext{
* This article is a revised version of the Paper submitted in the National Youth Festival Conference under the theme for the Youth by the Youth held at Sawa, Eritrea from 23-28 July, 2004.
} 
Rena, Ravinder (2006) "Education and Youth in Post-independent Eritrea - An Analytical Study", Albany (USA): The African Symposium (ISSN: TX 6-342-323), Volume 6., No. 3 and 4 (September and December) , pp.85-94 (An On-line Educational Research Quarterly Journal - A Publication of the African Educational Research Network).

provides researchers as well as policy makers with a useful framework for analysis of the interlinked relationships between education and poverty reduction. In the context of Eritrea, Sen's view is relevant in a way that education brings a positive social change.

Eritrea is bordered on the north-east by the Red Sea, on the south-east by Djibouti, on the south by Ethiopia and on the west and north-west by Sudan. Eritrea is also bordered with Saudi Arabia and Yemen across the Red Sea. The 45,754 square miles, which make up Eritrea, include over 350 islands. The population of Eritrea is about 4 million out of which one million citizens live outside of the country, a result of the colonial situation that prevailed in the country for three decades (Rena, 2006).

\section{Educational Background Of Eritrea}

The educational system in Eritrea shows all the symptoms of prolonged neglect under conditions of colonialism and war. Decades of conflict and the recent border turmoil have led to the devitalisation of education in the country. As a result, Eritrea has had to undergo a process of rehabilitating its educational institutions and services that were devastated during the long war (Petros, 2000). After obtaining independence, the government of Eritrea has exerted strenuous efforts in rebuilding the education system from the scratches of war and destruction (Rena, $\left.2005^{\mathrm{a}}\right)$.

Before the independence of Eritrea, the Derg regime systematically dismantled the education infrastructure and corrupted the education system consequently degraded the education standard to one of the lowest even by African standard (Rena, 2002: 3). The lack of regular maintenance of the infrastructure also meant that all institutional buildings were in a state of disrepair. Amazingly, many of the outdated, rigid and unfair systems introduced by the consecutive colonial Governments are still maintained by an independent Eritrea (Rena, 2005 ${ }^{\mathrm{a}}$ ). Hence, the government is attempting to introduce a new education system, i.e., 'rapid transformation of education' that is firm and fair, as well as flexible, and of the highest standard.

The rest of the paper is organized as follows: Section two presents the educational development in post-independent Eritrea with certain challenges; section three deals with education and economic growth; section four discusses the youth and education in Eritrea; and, section five provides concluding remarks of the paper.

\section{EDUCATIONAL DEVELOPMENT IN POST-INDEPENDENT ERITREA}

As the Chinese adage says "If you are thinking one year ahead Sow seeds, If you are thinking ten years ahead Plant a tree. If you are thinking 100 years ahead educate the people." Since Independence, the government of Eritrea has embarked on a wide-ranging program designed to revitalize and develop the collapsed economy and to promote the country's long-term growth. The overall vision of Eritrea's future progress is ultimately based on human capital formation, with education and health as key objectives (Government of the State of Eritrea, 1994).

In Eritrea, over the last fifteen years, there has been a phenomenal increase in enrollment. The number of schools at all levels (Junior, Middle, Secondary and Technical) increased from 293 in 1990-91 to 1000 in 2002-2003, while the numbers of teachers increased from 5,286 to more than 10,000 (see appendix table-1). The total number of students at all levels was about 186,000 in 1991 and reached to about 700,000 in 2006. In addition, Eritrea now has Asmara University, Asmara Commercial College, Teacher Training Institutes (TTI), and a number of other technical and vocational institutions. Two remarkable developments in the education sector of Eritrea are the opening of the Eritrean Institute of Technology- Mai Nefhi and of the Orotta School of Medicine (both started in February, 2004). Furthermore, a number of additional colleges have been established, such as the College of Agriculture - Hamalmalo, the College of Marine Science and Technology- Massawa, the College of Business and Economics - Massawa, and the College of Social Sciences- Adi Queh, to name a few (Rena, 2004: 6). The University of Asmara is 
Rena, Ravinder (2006) "Education and Youth in Post-independent Eritrea - An Analytical Study", Albany (USA): The African Symposium (ISSN: TX 6-342-323), Volume 6., No. 3 and 4 (September and December) , pp.85-94 (An On-line Educational Research Quarterly Journal - A Publication of the African Educational Research Network).

providing its academic programs in 43 departments encompassed in nine colleges: the College of Agriculture; the Faculty of Arts; the College of Business and Economics; the Faculty of Law; the College of Sciences; the Faculty of Education; the Faculty of Engineering; the College of Health Sciences; and, the College of Social Sciences. In addition, the University has launched post graduate programs in English, Economics, Geography, and Agriculture during the 2004-2005 academic year. Asmara University graduated 776 students in 2003, but jumped to approximately 2000 in the years 2004 and 2005 (see appendix table-4). During the 2000-2001 academic year, enrollment in elementary education increased by 1.0 per cent as compared to 1999-2000. The enrolment of girls in elementary education in 2000-2001, also, increased by 1.0 percent as compared to the previous year, whereas, the enrolment in middle and secondary education increased by about 3.0 percent and 7.3 percent, respectively (Rena, 2006).

The main asset of Eritrea is its human capital, the effective utilization of which is the crucial factor in determining the growth and prosperity of the economy of the country. In addition, the skill and talent of these individuals are critical to obtain maximum results. Realizing the importance of the human factor in the national economy, the Government of Eritrea has geared up all the possible ways to increase the number of required, skilled employees for its thirsty economy (Rena, 2005 ${ }^{\mathrm{b}}$ ). To do this, Eritrea is tackling the planning and implementing of clear cut and fast targeted Human Resource Development (HRD) policies, which are designed to ensure the optimization of available resources and to develop them for the future challenges. It is observed that, most of the HRD programmes of the Ministry of Education (MoE) are being systematically and successfully carried out by institutions involved in the process, such as the University of Asmara and the Department of Technical Education and Vocational Training (DTEVT), both of which have been playing a predominant role in the human resource development of Eritrea (Rena, 2006).

During the academic year 2002-2003, Eritrea harvested its fruit of educated manpower who were expected to shoulder the responsibility of building the nation from within their respective educational sectors. During this last academic year, 2005-2006, at least 724 students graduated from various schools and colleges under the DTEVT. Within the commercial stream, Asmara Commercial College produced a total of 206 graduates with diplomas, from both their day and extension programs. In the technical field, Pavoni Technical Institute ${ }^{1}$ produced 22 graduates; Asmara Technical School - 166; Wina Technical School - 86; Maihabar Technical School - 122; and Don Bosco Technical School - 42. Overall, since the 1991-92 academic school year, a total of 4,347 graduates have come out of the eight DTVET institutions in the country. Most of these graduates are serving in different government and private institutions and, thus, cater to the labor market needs of the country in a larger extent (Rena, 2004).

In other fields outside of the DTVET, the Hamelmalo Agricultural School and the Hagaz Agricultural School produced 54 and 75 graduates respectively (see appendix tables 2 and 3). In addition to the large number of graduates within the DTEVT realm, the Asmara Teacher Training Institute produced approximately 525 trained teachers and the Mainefi Mother Tongue Teachers Training Institute commemorated another 336 students (Rena, 2004). In the arts, the Asmara School of Music graduated 26 students in 2006, and in hospitality, The Tourism and Hotel Training School, has trained a total of 657 personnel in basic tourism and hotel service skills since its inception in 1998, just 8 years ago. Finally, attention should be given to the unique situation in Mekerka, Gash Barka, where approximately 300 females successfully graduated from a three-year course given by the Ministry of Justice in July 2003. All the graduates that have emerged from these schools are professionals equipped with profound skills and knowledge in a variety of technical and vocational fields, all of which are relevant to the immediate need of the Eritrean nation. Most of the graduates come from the intermediate level of education, but a full 1,002 graduates completed degrees at the advanced college level from 1996-97 to 2003-04. Only two of the schools mentioned above, the Asmara Technical Institute and the Asmara Commercial College, are at the advanced level. All of these individuals are gainfully employed and self- 
Rena, Ravinder (2006) "Education and Youth in Post-independent Eritrea - An Analytical Study", Albany (USA): The African Symposium (ISSN: TX 6-342-323), Volume 6., No. 3 and 4 (September and December) , pp.85-94 (An On-line Educational Research Quarterly Journal - A Publication of the African Educational Research Network).

sufficient citizens who can contribute greatly to their country's development. See Appendix Table 2 for the breakdown in graduates by gender and year at the intermediate level. Appendix Table 3 provides the statistics for graduates from the advanced college level by gender and year.

The increasing numbers of graduates from all fields is creating a new generation of skilled manpower that is balanced between both general and technical, or vocational, fields. The education and in-service training for teachers, and other professionals, is being systematically organized and is a response to the development needs of the country for appropriate education at all levels. This prosperity in education is obviously a great advancement for Eritrea and its citizens, and directly contributes to the realization of the dream to make Eritrea a technologicaloriented and advanced nation. The cumulative effort of all involved is finally reaping fruit. However, Eritrea faces certain challenges in the sector (Rena, 2006).

\section{Educational Challenges In Eritrea}

The challenge of educational development in Eritrea is a daunting one. Although there has been an enormous increase in demand for schooling and a corresponding growth in enrolment of those able to enter the formal education system, repetition and dropout rates are high. This is explained by the poor quality of education being received by children and the limited learning achievements being attained. The quality of education has been assessed with regard to what is taught, how it is taught, to which children and in what kind of setting. Most schools in Eritrea suffer from poor learning conditions; dilapidated or partially completed buildings; insufficient desks and text books; overcrowded classrooms; few or no learning materials; and poorly trained or unmotivated teachers (MoE, 1996).

The most urgent challenge facing educational reform in Eritrea remains the need to increase the access of school-aged children to primary schooling opportunities. Another major challenge is the how to retain the students who are already enrolled, and, how to ensure that the school system has the ability to offer those enrolled a quality education. In addition, a number of educational institutions in Eritrea are currently facing financial and other crises (Rena,2005 ${ }^{\mathrm{b}}$ ). They are not in a position to make available to their students world-class services, due to the limited ability to find ways to generate internal resources. Often times, the parents are unduly burdened by tacking up the slack.

\section{EDUCATION AND ECONOMIC GROWTH}

In Eritrea, education is important because it promotes the knowledge, skills, habits, values, attitudes, and understanding of the people of the country and thus make a positive contribution in developing Eritrean society. Education, indeed, helps Eritrean youth to become useful members of society. It also helps the youth to develop an appreciation of their cultural heritage and live more satisfying lives. The most common way to get an education is to attend school, college, or a university. These opportunities have become increasingly important as social changes today take place with increasing speed and greatly affect the lives of the people of Eritrea. Education contributes to economic growth in varied forms(Rena, 2005 $)$. Education contributes directly to economic growth through differential productivity of human capital. Hence, education, unquestionably, can be considered a good investment in economic growth (Psacharopoulos and Woodhall, 1985; Rena, 2002).

Education, like other forms of investment in human capital, contributes to economic development and raises the incomes of poor as much as it does the investment in physical capital, such as transportation, communication, power, or irrigation (Psacharopoulos and Woodhall, 1985: 3). Furthermore, education is now universally recognized as a form of investment in human beings, which yields economic benefits and contributes to a country's future wealth by increasing the productive capacity of its people (Woodhall, 1992:11). Therefore, investment in higher education can be a key contributor to a country's economic growth (Rena, 2000). 
Rena, Ravinder (2006) "Education and Youth in Post-independent Eritrea - An Analytical Study", Albany (USA): The African Symposium (ISSN: TX 6-342-323), Volume 6., No. 3 and 4 (September and December), pp.85-94 (An On-line Educational Research Quarterly Journal - A Publication of the African Educational Research Network).

\section{Financing of Education in Eritrea:}

In Eritrea, educational expenditure is generally expected to conform to a predetermined growth path. In essence, educational expenditure is believed to depend uniquely upon the spending power of the country. As the spending power on education increases, it will in turn increase the country's economy in greater than proportional levels (Rena, 2004). The Government of the State of Eritrea has been concentrating on the educational development of the country since Independence and it is responsible for the major share of all expenditure on education. The amount allotted for the development of education in the country dramatically increased from $\mathrm{Nfa}$ 35 million in 1992 to $\mathrm{Nfa} 287.3$ million in 2002. At this stage, however, it is not possible to precisely determine the percentage of GNP spent on education. It would suffice to say that the government's investment has been enormous (Rena, 2005 ).

Although the overall government contribution has been increasing for the last decade, it has not been able to keep pace with the rapid rise in enrollment and escalation in prices. Often the inadequacy of financial resources leads to poor infrastructure and physical facilities, low investment in research and development, and has an adverse impact on the quality and efficiency of the education system. Hence, the Government is trying to encourage private sector involvement in the running of schools at different levels. Currently, however, the participation level is low. For example, the private sector, in 1999-2000, accounted for only 13 per cent of enrollment, and in pre-primary education, which is entirely run by the private sector; only 3.4 per cent of children were enrolled.

\section{Education and Human Capital in Eritrea:}

The Eritrea Ministry of Education has played a very prominent role in re-building the economy. The successful implementation of human resource development plans depends substantially upon relevant policies and practices of other developed and developing countries apart from Eritrea's own internal policies and constraints. This noble achievement is evident in the present educational programmes and current reforms that have been developed in the country (Rena,2006).

In Eritrea, human capital formation plays a commanding role in triggering the process of socioeconomic transformation. The formation of human capital is influenced tremendously by the standard of education made available by Eritrean educational institutions. Since the majority of the education system is under the control of Eritrean Government, with the provision of education subject to financial restrains, the Government of Eritrea has taken responsibility for trying to foster the growth of human capital.

\section{YOUTH AND EDUCATION IN ERITREA}

Of importance is the face that Eritrean youth have been in the forefront of all historically registered national engagements. For example, the youth had a prominent position and participation during the thirty years freedom struggle (1961-1991). They also led the first postindependent development plan aimed at transforming the country's economy. They, also, played a vital role during the border conflict from 1998-2000 in safeguarding the country and reconstructing the economy.

Given that upgrading youth capabilities will strengthen their position as the cornerstone in the advancement of the country, the Government of Eritrea is undertaking youth rehabilitation and qualification programmes in various fields and, accordingly, giving them more emphasis. As an example of this, Eritrea has allocated more than 4 per cent of its national income, and more than 37 per cent of budget services, for educational programmes (Rena, 2005 ). This is indeed a major indication of the concern of states regarding the development of human resources. This 
Rena, Ravinder (2006) "Education and Youth in Post-independent Eritrea - An Analytical Study", Albany (USA): The African Symposium (ISSN: TX 6-342-323), Volume 6., No. 3 and 4 (September and December) , pp.85-94 (An On-line Educational Research Quarterly Journal - A Publication of the African Educational Research Network).

financial investment translates directly into the building of pre-schools (kindergartens), elementary and secondary schools, all the way up to university education.

Eritrean youth are solid assets of the country. The country could not have put its economy onto a successful development path without the readiness of its citizens, especially its youth. Hence, youth in Eritrea are playing a pivotal role in the reconstruction of the economy and the Warsay Yikealo National Development Campaign. Recognizing this, the Eritrean government is trying to provide the privilege of education to those youth who have participated in such development activities as a kind of incentive. For example, the 5,500 youth that took the first matriculation exam in the Warsay Yikealo Secondary School were given the opportunity to continue learning in the Eritrea Institute of Technology (EIT), Mai Nefhi. Additionally, the 8,500 students who took the matriculation exam in July 2005 are joined the EIT. Every year substantial number of students is joining in EIT.

In Eritrea, after students' complete grade XI, they will go on to attend the Warsay Yikealo Secondary School at Sawa ${ }^{2}$ to complete grade XII and take the matriculation exam. Based on the exam results, the students are then assigned to either EIT- Mai Nefhi or other colleges in the country. With such strong academic opportunities available to them, Eritrean youth have a good chance of finding ways of supporting their own life and the life of their families.

Hence, it is imperative to enable citizens through education and skill enhancement is more critical today to bring the social and economic change. There is fairly well-founded concern that in the next decade, Eritrea could find itself performing a difficult balancing act: catering to the needs of a significantly large growing population while trying to find opportunities for a newly emerging workforce of youth that does not have marketable skills. It is to be noted that thousands of youth enter the workforce each year in Eritrea without the benefit of a high school education and most have no skills for the job market. This must come as a sobering reality to those who are euphoric about the nation powering its way to superpower status in the foreseeable future.

The imparting of skills largely depends on the Industrial Training Institutes (ITIs) and technical schools that have a base in the public and private sectors of Eritrea. The ITI system, despite some attempts at a revamp, is viewed as insufficient and weighed down by factors such as the limited range of skills taught, outdated technology, high cost, and the requirement that those entering the system possess at least a high school qualification. The challenge before the State, therefore, is to build on the existing infrastructure of ITIs, schools, colleges, and institutions in the private sector. Computers and multimedia now make it possible to learn in an interactive manner and should help form the core of any new strategy. The potential of multimedia to train both literate and illiterate youth makes it all the more attractive. Courses in the service sector areas, such as tourism and health care, could be taught at centers employing such technology, in addition to the existing schools and colleges in Eritrea.

The youth's economic reconstruction efforts have been successful in improving the quality of the country's infrastructure. The overall reliability of the supply of power, transport and communication services has been restored and improved substantially in most parts of the country through the Warsay Yikealo Development Campaign. Eritrean youth not only cherish deep memories of their aspirations to break the fetters of colonial rule, but also renew their pledge to build the Homeland and create a solid foundation embodied with the concepts of ardent patriotism, unshakable unity, and hard work. Hence, the youth have a strong belief and confidence that "we can do it and we will do it".

\section{CONCLUDING REMARKS}

Colonizers systematically degraded the Eritrean education system; subsequently, Eritrea faces many challenges in the redevelopment of education. Since independence, education in Eritrea has shown considerable progress. The Government has established a number of schools and 
Rena, Ravinder (2006) "Education and Youth in Post-independent Eritrea - An Analytical Study", Albany (USA): The African Symposium (ISSN: TX 6-342-323), Volume 6., No. 3 and 4 (September and December), pp.85-94 (An On-line Educational Research Quarterly Journal - A Publication of the African Educational Research Network).

colleges, and also developed its human resources in order to improve the quality of life of the people. Although there has been considerable expansion in the education sector, particularly in the creation of vocational and technical schools and science and technology institutes in different parts of the country, Eritrea still has a very long way to go.

Eritrean youth have played an important part in contributing to the reconstruction and development of the Eritrean economy. One could propose that these skills and knowledge have the power to change the shape of Eritrea's future. If Eritrea wishes to capitalize on this power, it must promote mass education problems in order to eradicate superstition and cultural stigmas, which are impediments to education and prolific in the rural areas. The focus of these educational programmes should be aimed at raising the capabilities and capacity of its citizens. Therefore, the policymakers and practitioners must go deeper in exploring the internal strengths, weaknesses of youth in Eritrea and needs to go wider in seeking external support. Policy-makers must take into account the representative situations of different educational institutions at the higher level and formulate into objectives of a new policy because it is teachers and students at this level who brings the social change through education.

\begin{abstract}
Notes
${ }^{1}$ Asmara Technical Institute former name was Pavoni Technical Institute established by an Italian NGO. Then the MoE handed over the management in 2002. In the year 2006-2007 the MoE gave it to the state owned institute Asmara Commercial College.

${ }^{2}$ There is one area of continuity with Eritrean People's Liberation Front (EPLF)'s earlier practices; national service is required of all young people (men and women alike) who did not previously serve in EPLF. They receive six months of military training and are then deployed in rural areas for a year to help with road building, reforestation, and other projects. Some Muslim Eritreans have tried to argue for the exemption of Muslim women and some families apparently tried to use marriage as an exemption for women, but the government has held fast to the requirement that all young citizens regardless of Contradictions of Liberation and Development in Eritrea 153 gender, religion, or marital status must do their national service. The requirement of not only national service but military training for women is a significant legacy of EPLF's revolutionary culture. It also can be interpreted as emphasizing the supreme authority of the government over its female citizens over and above patriarchal domestic and religious authorities.
\end{abstract}

\title{
REFERENCES
}

Government of the State of Eritrea (1994). Macro Policy Document. Asmara: Government Printing Press.

Government of the State of Eritrea (2003), Ministry of Education - Statistical Bulletin 2002-2003, Asmara: Ministry of Education.

Ministry of Education (1996). Eritrea: Quest for Education. Asmara: Government Printing Press, Ministry of Education ( March 1998). Education in Brief. Asmara: Ministry of Education

Petros Hailemariam (2000). The Challenges of Educational Reconstruction and Transformation in Eritrea. In Teame Mebratu; Michael Crossley; David Johnson (eds.), Globalization, Educational Transformation and Societies in Transition, UK: Symposium Books (pp. 127-136).

Provisional Government of Eritrea (PGE -1991). Declaration of Policy on Education, Asmara: Government Printing Press.

Psacheropoulos, G. and Woodhall, M., (1985). Education for Development: An Analysis Of Investment Choices. Washington, D.C.: The World Bank Publication. 
Rena, Ravinder (2006) "Education and Youth in Post-independent Eritrea - An Analytical Study", Albany (USA): The African Symposium (ISSN: TX 6-342-323), Volume 6., No. 3 and 4 (September and December) , pp.85-94 (An On-line Educational Research Quarterly Journal - A Publication of the African Educational Research Network).

Rena, Ravinder (2000). Financing and Cost Recovery in Higher Education: A Study with Special Reference to Private Colleges in Andhra Pradesh. Unpublished Ph.D. thesis Submitted to the Department of Economics, Osmania University, Hyderabad, India for the Award of Doctoral Degree in Economics.

Rena, Ravinder(2002). Education: the Basis for Development in Eritrea. Asmara: Eritrea Profile, 9(40), p.3.

Rena, Ravinder (2004). Educational Development in Eritrea. Asmara: Eritrea Profile, 11(12), p. 6.

Rena, Ravinder $\left(2005^{\mathrm{a}}\right)$. Eritrean Education - Retrospect and Prospect, Nairobi (Kenya ): Eastern Africa Journal of Humanities and Sciences,.5(2).1-12.

Rena, Ravinder $\left(2005^{\mathrm{b}}\right)$. Financing of Education in Eritrea - A Case Study on Zoba Maakel, Albany (USA): The African Symposium, 5(3) 113-128.

Rena, Ravinder (2006). Education and Human Resource Development in Post-independent Eritrea- An Analysis. Barbados: West Indies, International Journal of Education and Development using Information and Communication Technology (IJEDICT), 2 (4).

Sen, A.K. (1999). Development as Freedom. New Delhi: Oxford University Press.

Woodhall, Mureen (1992). Cost-Benefit Analysis in Educational Planning. Paris: UNESCO- IIEP.

Appendix Table -1 Male and female students in secondary schools from 1991 to 2003

\begin{tabular}{|l|c|c|c|}
\hline $\begin{array}{l}\text { Academic } \\
\text { Years }\end{array}$ & $\begin{array}{c}\text { Total Student } \\
\text { Population }\end{array}$ & $\begin{array}{c}\text { Percentage of } \\
\text { Female Students }\end{array}$ & $\begin{array}{c}\text { Percentage of Male } \\
\text { Students }\end{array}$ \\
\hline $1991 / 92$ & 27,627 & 48 & 52 \\
\hline $1995 / 96$ & 39,188 & 40 & 60 \\
\hline $1999 / 00$ & 59,626 & 37 & 63 \\
\hline $2002 / 2003$ & 68,857 & 33.4 & 66.6 \\
\hline
\end{tabular}

Source: Ministry of Education Various Reports.

Appendix Table-2: Graduates of Intermediate Level by Gender and Year

\begin{tabular}{|l|c|c|c|}
\hline Year & \multicolumn{3}{|c|}{ Number of Graduates } \\
\hline & Male & Female & Total \\
\hline 1991 & 115 & 18 & 133 \\
\hline 1992 & 120 & 23 & 143 \\
\hline 1993 & 86 & 7 & 93 \\
\hline 1994 & 205 & 31 & 236 \\
\hline 1995 & 182 & 19 & 201 \\
\hline 1996 & 130 & 12 & 142 \\
\hline 1997 & 177 & 21 & 198 \\
\hline 1998 & 164 & 25 & 189 \\
\hline 1999 & 126 & 22 & 148 \\
\hline 2000 & 252 & 44 & 296 \\
\hline 2001 & 263 & 57 & 320 \\
\hline 2002 & 443 & 80 & 523 \\
\hline 2003 & 492 & 179 & 671 \\
\hline 2004 & 434 & 90 & 524 \\
\hline 2005 & 409 & 121 & 530 \\
\hline Total & 3,598 & $\mathbf{7 4 9}$ & $\mathbf{4 , 3 4 7}$ \\
\hline
\end{tabular}

Source: Dept. of Technical and Vocational Education Training, MoE - various documents. 
Rena, Ravinder (2006) "Education and Youth in Post-independent Eritrea - An Analytical Study", Albany (USA): The African Symposium (ISSN: TX 6-342-323), Volume 6., No. 3 and 4 (September and December) , pp.85-94 (An On-line Educational Research Quarterly Journal - A Publication of the African Educational Research Network).

Appendix Table-3: Graduates of Advanced Level by Gender and Year.

\begin{tabular}{|l|c|c|c|}
\hline Year & \multicolumn{3}{|c|}{ Number of Graduates } \\
\hline & Male & Female & Total \\
\hline $1991 / 92$ & 0 & 0 & 0 \\
\hline $1992 / 93$ & 0 & 0 & 0 \\
\hline $1993 / 94$ & 0 & 0 & 0 \\
\hline $1994 / 95$ & 0 & 0 & 0 \\
\hline $1995 / 96$ & 0 & 0 & 0 \\
\hline $1996 / 97$ & 39 & 16 & 55 \\
\hline $1997 / 98$ & 0 & 0 & 0 \\
\hline $1998 / 99$ & 98 & 46 & 144 \\
\hline $1999 / 00$ & 139 & 58 & 197 \\
\hline $2000 / 01$ & 55 & 20 & 75 \\
\hline $2001 / 02$ & 87 & 20 & 107 \\
\hline $2002 / 03$ & 165 & 67 & 232 \\
\hline $2003 / 04$ & 160 & 32 & 192 \\
\hline $2004 / 05$ & 0 & 0 & 0 \\
\hline Total & $\mathbf{7 4 3}$ & $\mathbf{2 5 9}$ & $\mathbf{1 0 0 2}$ \\
\hline
\end{tabular}

Source: Dept. of Technical and Vocational Education Training, MoE - various documents.

${ }^{* *}$ Note: There are two colleges at Advanced level- they are: Asmara Technical Institute and Asmara Commercial College, both these colleges did not produce any graduates during the academic year 2004/05 due to the government policy and reopened in September 2006.

Appendix Table - 4 University of Asmara Graduates by Gender and Type of Course from 1996 to 2003.

\begin{tabular}{|l|c|c|c|c|c|c|}
\hline \multicolumn{4}{|l|}{ Certificate and Diploma } & \multicolumn{2}{l|}{ Degree } \\
\hline Year & Female & Male & Total & Female & Male & Total \\
\hline 1996 & 17 & 54 & 71 & 56 & 367 & 423 \\
\hline 1997 & 26 & 90 & 116 & 46 & 356 & 402 \\
\hline 1998 & 14 & 111 & 125 & 33 & 292 & 325 \\
\hline 1999 & 32 & 207 & 239 & 62 & 492 & 554 \\
\hline 2000 & 47 & 234 & 281 & 42 & 336 & 378 \\
\hline 2001 & 50 & 276 & 326 & 69 & 537 & 606 \\
\hline 2002 & 78 & 428 & 506 & 74 & 546 & 620 \\
\hline 2003 & - & - & 207 & - & - & 776 \\
\hline
\end{tabular}

Source: University of Asmara, Registrar Office - Documents. 